\title{
CT-scan findings of COVID-19 pneumonia based on the time elapsed from the beginning of symptoms to the CT imaging evaluation: a descriptive study in Iran
}

\author{
SIROUS JAFARI ${ }^{1, \dagger} ;$ MOHAMMADREZA TABARY $^{2, \dagger} ;$ SAHEREH ESHRAGHI $^{1}$; FARNAZ ARAGHI ${ }^{3}$; \\ ARMIN ARYANNEJAD ${ }^{2}$; ESMAEIL MOHAMMADNEJAD ${ }^{4} ;$ MEHRNAZ RASOOLINEJAD $^{1}$; \\ MAHBOUBEH HAJIABDOLBAGHI ${ }^{1}$; HAMID EMADI KOOCHAK ${ }^{1}$; ZAHRA AHMADINEJAD ${ }^{1}$; \\ LADAN ABBASIAN ${ }^{1}$; SEYED ALI DEHGHAN MANSHADI ${ }^{1}$; MOHAMMADREZA SALEHI ${ }^{1}$; \\ HOSSEIN KHALILI ${ }^{5}$; NILOOFAR AYOOBI YAZDI ${ }^{6}$ ARASH SEIFI ${ }^{1}$
}

\footnotetext{
${ }^{1}$ Department of Infectious Diseases, School of Medicine, Imam Khomeini Hospital, Tehran University of Medical Sciences, Tehran, Iran

${ }^{2}$ Experimental Medicine Research Center, Tehran University of Medical Sciences, Tehran, Iran

${ }^{3}$ Skin research center, Shahid Beheshti University of Medical Sciences, Tehran, Iran

${ }^{4}$ Department of Medical-Surgical Nursing and Basic Sciences, School of Nursing and Midwifery, Tehran University of Medical Sciences, Tehran, Iran

${ }^{5}$ Department of Pharmacotherapy, Imam Khomeini Hospital Complex, Tehran University of Medical Sciences, Tehran, Iran

${ }^{6}$ Department of Radiology, Liver Transplant Research Center, Imam Khomeini Hospital, Tehran University of Medical Sciences, Tehran, Iran

${ }^{\dagger}$ The first two authors contributed equally and are considered first authors
}

\begin{abstract}
Background. Coronavirus disease 2019 (COVID-19) was initially detected in Wuhan city, China. Chest CT features of COVID-19 pneumonia have been investigated mostly in China, and there is very little information available on the radiological findings occurring in other populations. In this study, we aimed to describe the characteristics of chest CT findings in confirmed cases of COVID-19 pneumonia in an Iranian population, based on a time classification.

Methods. Eighty-nine patients with COVID-19 pneumonia, confirmed by a real-time RT-PCR test, who were admitted to non-ICU wards and underwent a chest CT scan were retrospectively enrolled. Descriptive evaluation of radiologic findings was performed using a classification based on the time interval between the initiation of the symptoms and chest CT-scan.

Results. The median age of patients was 58.0 years, and the median time interval from the onset of symptoms to CT scan evaluation was 7 days. Most patients had bilateral (94.4\%) and multifocal (91.0\%) lung involvement with peripheral distribution (60.7\%). Also, most patients showed involvement of all five lobes (77.5\%). Ground-glass opacities (GGO) (84.3\%) and mixed GGO with consolidation $(80.9 \%)$ were the most common identified patterns. We also found that as the time interval between symptoms and CT scan evaluation increased, the predominant pattern changed from GGO to mixed pattern and then to elongated-containing and band-like-opacities-containing pattern; on the other hand, the percentage of lung involvement increased.

Conclusions. Bilateral multifocal GGO, and mixed GGO with consolidation were the most common patterns of COVID-19 pneumonia in our study. However, these patterns might change according to the time interval from symptoms.
\end{abstract}

Key words: COVID-19, SARS-CoV-2, computed tomography, pneumonia.

\section{INTRODUCTION}

Coronavirus disease 2019 (COVID-19), caused by severe acute respiratory syndrome coronavirus 2 (SARS-CoV-2), was initially detected in Wuhan city, Hubei province, China [1]. Afterward the virus had spread quickly throughout the world and was characterized as a pandemic by the World Health Organization (WHO) on March $11^{\text {th }}, 2020$. To date, over 13 million cases of COVID-19 have been confirmed around the world and more than 578,000 cases have expired [2]. The most common clinical features of COVID-19 include fever, cough, fatigue, and gastrointestinal symptoms [3, 4].

The virus invades human respiratory epithelial cells by interacting with human angiotensin-converting enzyme 2 (ACE2) receptor causing a cascade of further events which lead to pneumonia and other severe conditions, including kidney injury, central nervous system involvement, and cardiac injury 
[5-7]. Pneumonia is one of the main serious results of infection with the SARS-CoV-2 virus. It has been reported that about $20-25 \%$ of patients develop acute respiratory distress syndrome and require ICU admission following the COVID-19 pneumonia [8-10]. Recent studies found that chest computed tomography (CT) could be of great value for the early diagnosis of COVID-19 pneumonia [11-13]. Studies in China also indicated that chest CT might have higher sensitivity in comparison with the realtime RT-PCR test for SARS-CoV-2 COVID-19 pneumonia [14]. According to the studies on the Chinese population, CT findings included a wide spectrum ranging from unilateral focal opacity to diffuse bilateral ground-glass opacities and possibly to lung/pulmonary consolidation [11].

Chest CT characteristics of COVID-19 pneumonia have been investigated mostly in Chinese population; however, radiological findings should be elucidated in other populations and areas around the world, which have a rapidly growing number of confirmed cases. Also, there have been no studies on the CT findings in the Iranian population. As Iran has the largest number of confirmed cases in Asia after China, we aimed to describe the characteristics of chest CT findings in confirmed cases of COVID-19 pneumonia in the Iranian population.

\section{MATERIALS AND METHODS}

\section{PATIENTS AND STUDY DESIGN}

This retrospective study was performed in a large tertiary referral center "IKHC" (Imam Khomeini Hospital Complex, Tehran, Iran). One hundred patients with COVID-19 pneumonia, confirmed by a real-time RT-PCR test, who were admitted to non-ICU wards and underwent a chest CT scan were retrospectively enrolled in this study. Patients with underlying respiratory diseases (including chronic obstructive pulmonary disease, and interstitial lung disease) which could influence radiologic findings were then excluded from the study. Finally, 89 patients were enrolled for further evaluation and analysis. We then categorized patients in four groups based on the time interval between the onset of symptoms and chest CT scan evaluation: group 1 (0-3 days), group 2 (4-7 days), group 3 ( $8-13$ days), and group 4 (14 days or more). This classification was chosen due to the progression of disease. In other words, the interval from symptom onset to hospitalization was reported to be 4 days on average.
Also, more than half of the patients developed radiologic findings in 7 days, and most of the patients improved radiologically by day 14 [15]. This study was approved by the local ethics committee (reference code: IR.TUMS.VCR.REC.1399.146) and written consent was obtained from all the patients or their representative.

\section{CT SCAN DATA ACQUISITION AND ANALYSIS}

All the CT scans were performed using a multidetector CT scanner (Siemens, Munich, Germany) with detailed parameters as follows: tube voltage, $120 \mathrm{kV}$; tube current, standard (60-120 mAs); slice thickness, $1-1.5 \mathrm{~mm}$; reconstruction interval, $1-1.5 \mathrm{~mm}$. The CT scans were performed starting from the upper thoracic inlet to the costophrenic angle level foreach patient.

To provide more explicit information on CT scans, we designed a checklist based on the previous studies [9-11]. The checklist included the characteristics of CT scans, such as the lesion distribution (unifocal, multifocal, or bilateral), central to peripheral distribution, and the number of involved lobes. Specific characteristics of each lesion were also included in the checklist as follows:

- lobe of the lesion distribution: left upper, left lower, right upper, right middle, right lower

- axial location: central, peripheral, central and peripheral, peribronchovascular

- anteroposterior location: anterior, posterior, anterior and posterior

- type of the lesion: patchy to confluent, nodular, reticular

- the shape of the lesion: round, elongated, wedge, confluent

- patterns of the lesion: ground-glass opacity (GGO), consolidation, mixed ground-glass and consolidation, crazy paving pattern, cavitation, solid, part-solid, reversed-halo

- the margin of the lesion: ill-defined, welldefined

- other signs in the lesion: interlobular septal thickening, linear opacities combined, air bronchogram sign, tree-in-bud, or other signs

- other chest CT scan findings: adjacent pleura thickening, pleural effusion, centrilobular nodule, pericardial effusion, lymphadenopathy, pulmonary emphysema, or other findings

The extent of the involvement in both lungs was also measured in a subjective manner by two 
radiologists. Previous studies showed that subjective measurement is not meaningfully distinct from the computer-based measurement (size of lesions from subjective assessment correlates with computerbased evaluation) [16]. An expert radiologist in the field of chest CT scan, with experience in COVID19 images, analyzed the CT scans, and checked the designed checklists for each patient. Descriptive data were reported based on the median and interquartile range. Analyses were performed by SPSS software version 24.0 (IBM Corp., Armonk, NY, USA).

\section{RESULTS}

We included 89 patients (45 females) with confirmed COVID-19 pneumonia admitted to IKHC (Tehran, Iran). The median age of patients was 58.0 years $\left(1^{\text {st }}, 3^{\text {rd }} \mathrm{IQR}: 47.5,68.0\right.$; ranged $24-91$ years $)$. The median time from onset of symptoms to CT-scan evaluation was 7 days $\left(1^{\text {st }}, 3^{\text {rd }}\right.$ IQR: 3.5 , 10.0 days). Patients were assigned to four groups based on the time between the onset of symptoms and the first CT scan as follows: $22(24.7 \%)$ patients were assigned to group 1, $29(32.6 \%)$ were assigned to group 2, $24(27.0 \%)$ were assigned to group 3, and $14(15.7 \%)$ were assigned to group 4.

Most patients had bilateral and multifocal lung involvement which were observed in $94.4 \%$ and $91 \%$ of patients, respectively. Most of the patients had involvement of all five lobes $(77.5 \%)$. Only one patient had involvement of just one lobe, which was the left upper lobe. The lesions were mainly distributed in lower lobes with the left lower lobe and right lower lobes being the most common sites involved. Considering central to peripheral distribution, most patients had peripheral lesions $(60.7 \%)$. Interestingly, $82 \%$ of the patients had peribronchovascular lesions. Almost one-third of the patients had subpleural sparing in chest CT scans. Patchy lesion was the most common type of lesion which was observed in $97.8 \%$ of patients. Confluent and wedged lesions were the most two common shape of lesions observed in $82.0 \%$ and $80.9 \%$ of the patients. Of the 89 patients enrolled, $75(84.3 \%)$ had pure GGO pattern, $72(80.9 \%)$ had mixed GGO and consolidation pattern, 69 (77.5\%) presented with part-solid pattern, 53 (59.6\%) showed crazy-paving pattern, and $31(34.8 \%)$ had consolidation. Solid pattern and reversed-halo were the least common pattern observed in the patients. Only one patient presented with a cavity along with the reversed-halo sign with a well-defined margin. With the exception of the abovementioned patient, all other patients presented with ill-defined lesions. When considering all patients, 49 (55.1\%) showed air bronchogram, $48(53.9 \%)$ had linear opacities, $17(19.1 \%)$ had interlobular septal thickening, and $6(6.7 \%)$ showed tree-in-bud sign. Adjacent pleural thickening, pleural effusion, and cardiomegaly were also observed in $45(50.6 \%), 15(16.9 \%)$, and $30(33.7 \%)$ of the patients. Pulmonary trunk enlargement, pericardial effusion, and splenomegaly were uncommon imaging findings in the study population. Table 1 summarizes the patients-specific CT scan findings. Figure 1 illustrates the CT scan findings in a 51-year-old man 5 days after the onset of the symptoms.

The most common patterns observed in group 1 were GGO (33.3\% of this group) and mixed pattern (33.3\% of this group). Also, $95.5 \%$ and $90.9 \%$ of the lesions were bilateral and multifocal, respectively in group 1. Also, the reticular pattern was mostly observed in this group of patients (5 patients, 22.7\% of this group). Moreover, nodular lesions were mostly observed in this group (4 patients, $18.2 \%$ of this group). In group 2, the most common pattern, which was observed, was mixed pattern $(42.9 \%$ of the patients in this group). As the time interval increased in group 3, the most common pattern, which was observed, tended to be elongated-containing and band-like-opacities-containing pattern $(34.9 \%$ of this group). Air bronchogram sign was mostly observed in group 3 and group 2 (18, 15 patients; $62.1 \%$ and $62.5 \%$ of the patients in group 2 and group 3, respectively). Also, the crazy-paving pattern was mostly observed group 3 (18 patients, $75 \%$ of this group). The most common pattern, which was observed in group 4, was the GGO pattern $(35.8 \%$ of this group). Moreover, cardiomegaly was observed mostly in group 4 (6 patients, $42.9 \%$ of this group). Pleural effusion was observed in 6 $(27.3 \%), 4(13.8 \%), 1(4.2 \%)$, and $4(28.6 \%)$ of patients in group 1, 2, 3, and 4, respectively. Figure 2 shows the distribution of patterns among these 4 groups of the patients.

As the time interval between the symptom and CT scan evaluation increased, the percentage of the lung involvement rose. In group 1, almost half of the patients had less than $35 \%$ involvement of the lungs; however, almost half of the patients in group 4 presented with the involvement of more than $70 \%$ of the lungs (Figure 3 ). 
Table 1

Imaging findings of patients with SARS-CoV-2 at the first CT-scan

\begin{tabular}{|c|c|c|c|}
\hline & Patients $(n=89)$ & & Patients $(n=89)$ \\
\hline Distribution & & Central to peripheral distribution & \\
\hline Bilateral involvement & $84(94.4 \%)$ & Central & $10(11.2 \%)$ \\
\hline Multifocal involvement & $81(91.0 \%)$ & Peripheral & $54(60.7 \%)$ \\
\hline \multirow[t]{3}{*}{ Unifocal involvement } & $4(4.5 \%)$ & Central and peripheral & $32(36.0 \%)$ \\
\hline & & Peribronchovascular & $73(82.0 \%)$ \\
\hline & & Subpleural sparing & $26(29.2 \%)$ \\
\hline Number of involved lobes & & Involved lobes distribution & \\
\hline 0 & $1(1.1 \%)$ & Left upper lobe & $77(86.5 \%)$ \\
\hline 1 & $4(4.5 \%)$ & Left lower lobe & $85(95.5 \%)$ \\
\hline 2 & $3(3.4 \%)$ & Right upper lobe & $77(86.5 \%)$ \\
\hline 3 & $4(4.5 \%)$ & Right middle lobe & $77(86.5 \%)$ \\
\hline 4 & $8(9.0 \%)$ & Right lower lobe & $83(93.3 \%)$ \\
\hline 5 & $69(77.5 \%)$ & & \\
\hline Anteroposterior location & & Type of the lesion & \\
\hline Anterior & $10(11.2 \%)$ & Patchy & $87(97.8 \%)$ \\
\hline Posterior & $10(11.2 \%)$ & Nodular & $11(12.4 \%)$ \\
\hline Anterior and posterior & $75(84.3 \%)$ & Reticular & $13(14.6 \%)$ \\
\hline Shape of the lesion & & Other signs in the lesion & \\
\hline Round & $15(16.9 \%)$ & Interlobular septal thickening & $17(19.1 \%)$ \\
\hline Elongated & $30(33.7 \%)$ & Linear opacities & $48(53.9 \%)$ \\
\hline Wedged & $72(80.9 \%)$ & Air bronchogram & $49(55.1 \%)$ \\
\hline Confluent & $73(82.0)$ & Tree-in-bud & $6(6.7 \%)$ \\
\hline Amorph & $9(10.1 \%)$ & & \\
\hline Pattern of the lesion & & Other CT-scan findings & \\
\hline Pure GGO & $75(84.3 \%)$ & Adjacent pleural thickening & $45(50.6 \%)$ \\
\hline Consolidation & $31(34.8 \%)$ & Pleural effusion & $15(16.9 \%)$ \\
\hline Mixed GGO and consolidation & $72(80.9 \%)$ & Cardiomegaly & $30(33.7 \%)$ \\
\hline Crazy-paving appearance & $53(59.6 \%)$ & Pulmonary trunk enlargement & $2(2.2 \%)$ \\
\hline Cavitation & $1(1.1 \%)$ & Pericardial effusion & $5(5.6 \%)$ \\
\hline Solid & $15(16.9 \%)$ & Splenomegaly & $8(9.0 \%)$ \\
\hline Part-solid & $69(77.5 \%)$ & & \\
\hline Reversed halo & $10(11.2 \%)$ & & \\
\hline \multicolumn{4}{|l|}{ Margin of the lesion } \\
\hline Ill-defined & $76(85.4 \%)$ & & \\
\hline Well-defined & $1(1.1 \%)$ & & \\
\hline
\end{tabular}

GGO: ground-glass opacities 


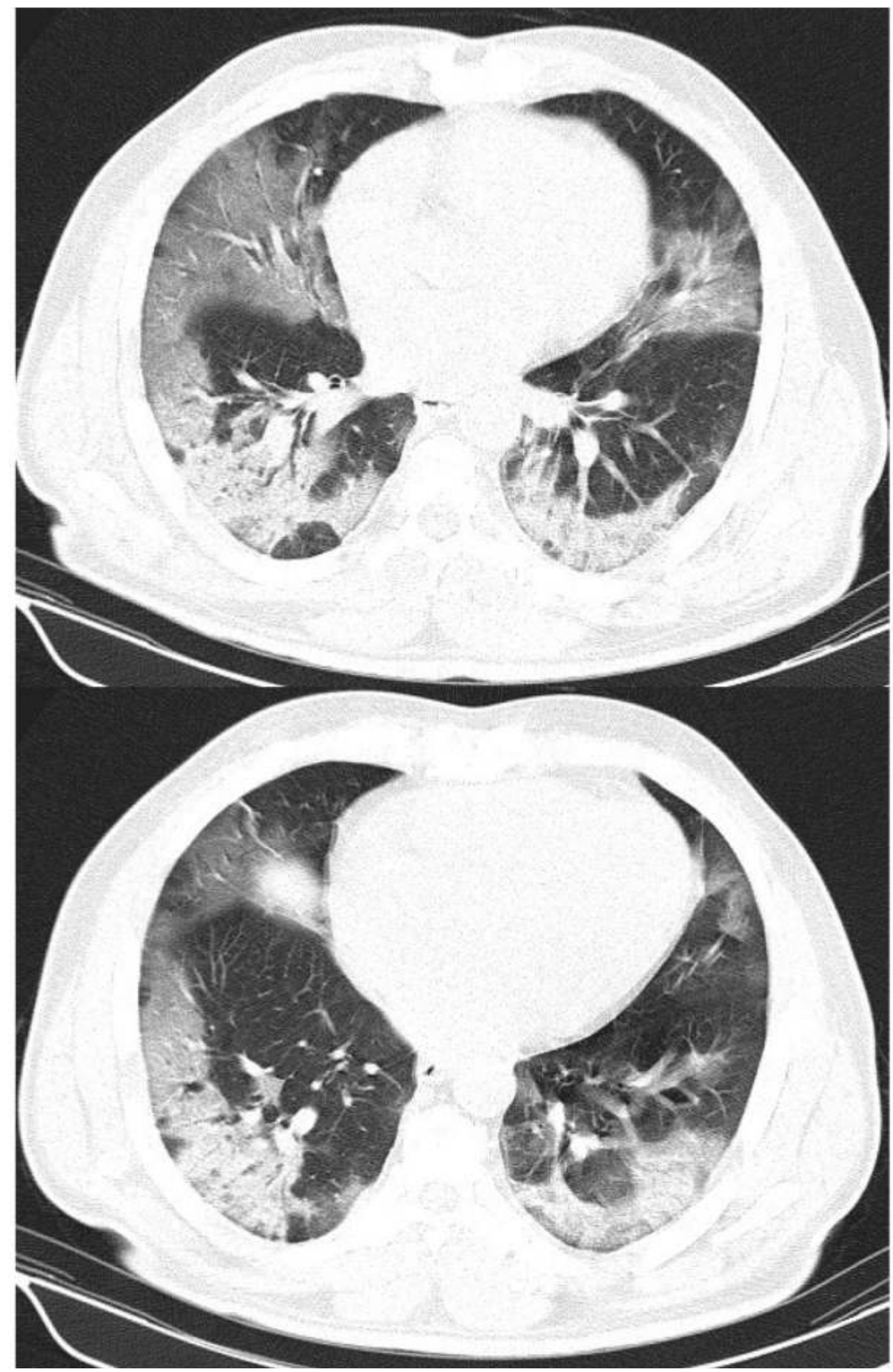

Figure 1. Transverse CT scan cut from a 51-year-old man after 5 days from the onset of symptoms. These two transverse cuts from the CT scan shows ground-glass opacities (GGO) in right and left lower lobes, right middle lobe, and lingula. Consolidation can be found in both right and left lower lobes. 


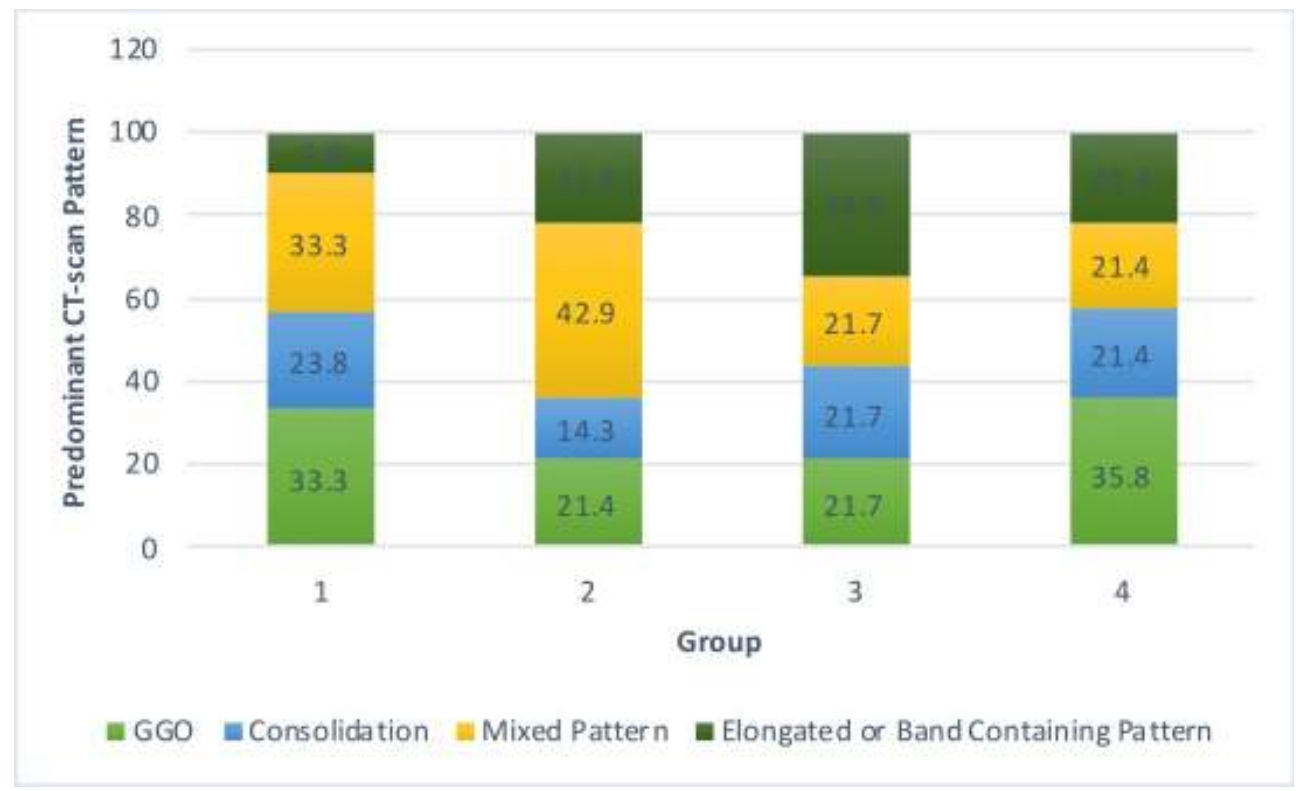

Figure 2. Distribution of various patterns of lung involvement on CT scan at different time points from the onset of symptoms.

The bars show the proportion of each pattern in groups 1-4. Patients were categorized into four groups based on the time interval between the onset of symptoms and chest CT scan: group $1(0-3$ days; $n=22)$, group $2(4-7$ days; $n=29)$, group 3 ( $8-13$ days; $n=24)$, and group 4 (14 days or more; $n=14)$.

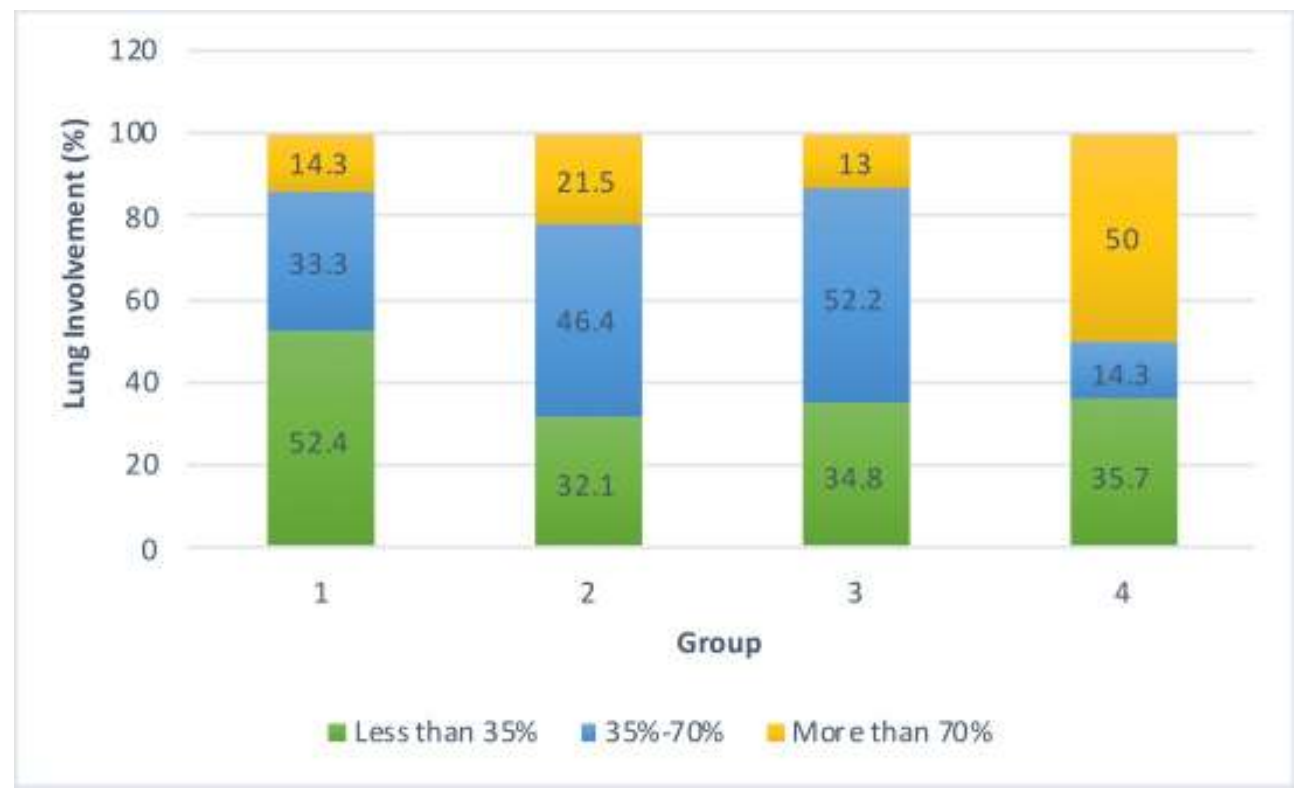

Figure 3. The extent of lung involvement on CT scan at different time points from the onset of symptoms. The bars show the proportion of the extent of lung involvement in groups 1-4. The extent of lung involvement was categorized into less than $35 \%, 35 \%-70 \%$, and more than $70 \%$. Patients were categorized into four groups based on the time interval between the onset of symptoms and chest CT scan: group $1(0-3$ days; $n=22)$, group $2(4-7$ days; $n=29)$, group 3 ( $8-13$ days; $\mathrm{n}=24)$, and group $4(14$ days or more; $\mathrm{n}=14)$.

\section{DISCUSSION}

The novel coronavirus SARS-Co-V-2 is the seventh member of the Coronaviridae family, with far more confirmed cases compared with SARSCoV 2002 and MERS-CoV in 2012 [17-20]. However, the mortality rates in COVID-19 seem to be lower in contrast to the other two mentioned members of this family. In this study, we found CT scan patterns distribution in the confirmed cases of COVID-19 pneumonia: bilateral multifocal GGO and mixed GGO and consolidation with a predilection for lower lobes and peripheral locations were the two most common pattern observed. The lesions were also accompanied by air bronchogram, linear opacities, and adjacent pleural thickening in half of 
the cases. We found that the predominant pattern varies widely, according to the time interval between symptom and CT scan evaluation.

COVID-19 pneumonia shares some similarities with SARS and MERS pneumonia, such as the predominance of bilateral peripheral GGO pattern [21-25]. However, previous reports showed milder involvement of the lung compared to SARS and MERS [13]. Unilateral involvement has been reported to be more common in the early phase of SARS, and MERS, but it was not a common finding in our study and other reports from COVID-19 pneumonia. More than half of the patients reported by a previous study showed bilateral multifocal lung involvement [12]. Similarly, we found multifocal involvement of both lungs, consistent with previous reports from COVID-19 [26]. The GGO pattern patients with COVID-19 corresponds to diffuse alveolar damage [27]. A GGO pattern is caused partial filling of the alveoli, which is associated with the pathogenesis of viral infections [28]. We found a predilection of the lesion for involving lower lobes consistent with previous findings in COVID-19 patients $[13,26]$. This predilection of the lesions for involving lower lobes was also observed in influenza pneumonia [28].

Some patients in our study presented with pleural effusion. This finding has been reported previously to be a poor prognostic indicator in MERS-CoV or avian influenza H5N1 infected patients $[21,22,29]$. A deceased case of COVID-19, in whom bilateral pleural effusion was observed, was also reported by previous studies [11]. Further studies are needed to fully address the prognostic power of this finding in the patients infected with SARS-CoV-2. Reversed-halo sign was observed in $11.2 \%$ of the included patients. This finding was reported by previous studies in COVID-19 patients [13, 30-32] and might reflect an organizing pneumonia pattern in COVID-19 patients [32]. We also observed the tree-in-bud pattern in 6 patients. This finding was not reported in any of the previous articles in COVID-19 patients. However, this finding was reported in cytomegalovirus and respiratory syncytial virus infections, although rarely [33, 34].

We also found that as the time interval between symptom and CT scan evaluation increased, the predominant pattern changed from GGO to mixed pattern and to elongated and band-like containing pattern. This change in predominant pattern towards elongated and band-like pattern may indicate the emergence of interstitial changes, suggesting the development of fibrosis, which was claimed by previous studies on COVID-19 subjects [11]. Fibrosis was also observed among survivors of SARS, which was explained by the epidermal growth factor receptor (EGFR) signaling pathway [35]. Future works are needed to determine the long-term effects of COVID-19 on the lung tissue.

This study indeed has some limitations. First, this study was cross-sectional and the images were not taken longitudinally in the same patient, but, on one hand, the study was retrospective and, on the other hand, more CT scans for the same patient without clinical necessity should not have been ethical.

Secondly, this is not a pathophysiology study; thus, we could only observe imagistic evolution of the lesions and not fully understand the course of the disease. We've focused on CT scan findings to provide a better picture of COVID-19 imaging features based on the timed elapsed from the onset of symptoms so that physicians may become more aware of the diverse CT scan manifestations of COVID-19 at different time points. The aim of this study was to elucidate the CT-scan patterns of COVID-19 in association with the time of symptoms onset. We could not fully record patients' clinical data because we performed this study amid the peak of pandemic in Tehran and we lacked adequate staff to completely record all clinical data. This study will serve as a guide for better diagnosis, since many studies have evaluated the correlation of clinical symptoms and CT images, as well as the outcome.

\section{CONCLUSION}

Bilateral multifocal GGO and mixed GGO and consolidation were the most common patterns of COVID-19 pneumonia observed in our study population. The lesions were mainly distributed in lower lobes, and patchy lesions were the most type of lesions observed among patients. Also, the dominant pattern changed according to the time interval from symptoms (elongated-containing and band-likeopacities-containing pattern became more popular after the first week).

Introducere. Boala dată de coronavirus 2019 (COVID-19) a fost iniţial detectată în Wuhan, China. Aspectele CT ale pneumoniei COVID-19 au fost 
investigate mai ales la populaţia chineză şi în literatură sunt puţine studii care evaluează aceste aspecte în alte grupe populaţionale. Scopul studiului a fost de a descrie caracteristicile CT la pacienţi confirmaţi cu pneumonie COVID-19 din Iran.

Metode. 89 de pacienţi cu pneumonie COVID-19 confirmaţi prin real time PCR admişi în camere de gardă non-ATI şi care au fost supuşi analizei CT toracic au fost analizaţi retrospectiv. Au fost evaluate caracteristicile descriptive ale aspectelor radiologice.

Rezultate. Mediana vârstei a fost de 68 de ani, iar intervalul de timp scurs de la debutul simptomatologiei şi analiza CT a fost de 7 zile. Cei mai mulţi pacienţi au avut afectare pulmonar bilaterală (94,4\%) şi multifocală (91\%) cu distribuţie perifierică (60,7\%). Majoritatea pacienţilor au avut toţi cei 5 lobi afectaţi $(77,5 \%)$. Opacităţile difuze în geam-mat (84,3\%) şi opacităţi cu consolidare (80.9\%) au fost caracteristicile cele mai frecvent întâlnite. Am observat că pe măsură ce distanţa temporală dintre debutul simptomelor şi realizarea CT-ului toracic a crescut tipul de modificări radiologice a evoluat spre un aspect mixt şi finalizând cu opacităţi în bandă. Pe de altă parte procentul din masa parenchimatoasă afectat a scăzut.

Concluzii. Aspectul bilateral multifocal de opacitate în geam mat şi opacitate în geam mat cu consolidare a fost cel mai frecvent pattern în pneumonia cu COVID-19 din studiul nostru. Dar aceste aspecte par să fie dinamice pe măsură ce boala evoluează.

Correspondence to: 1 . Arash Seifi, Department of Infectious Diseases, School of Medicine, Imam Khomeini Hospital, Tehran University of Medical Sciences, Tehran, Iran

E-mail: a-seifi@sina.tums.ac.ir

2. Niloofar Ayoobi Yazdi, Department of Radiology, Liver Transplant Research Center, Imam Khomeini Hospital, Tehran University of Medical Sciences, Tehran, Iran

E-mail: nayoobi@sina.tums.ac.ir

Conflict of interest disclosure: None to declare.

Acknowledgments: This study was funded and supported by Tehran University of Medical Sciences (TUMS); Grant no. 99-1-10147391.

\section{REFERENCES}

1. WHO. Novel coronavirus - china 2020, January 12 [Available from: https://www.who.int/csr/don/12-january-2020-novel-coronaviruschina/en/.

2. https://www.worldometers.info/coronavirus/. 2020 [updated 07/14/2020.

3. YANG W, CAO Q, QIN L, WANG X, CHENG Z, PAN A, et al. Clinical characteristics and imaging manifestations of the 2019 novel coronavirus disease (COVID-19): A multi-center study in Wenzhou city, Zhejiang, China. Journal of Infection. 2020.

4. ZHANG JJ, DONG X, CAO YY, YUAN YD, YANG YB, YAN YQ, et al. Clinical characteristics of 140 patients infected by SARS-CoV-2 in Wuhan, China. Allergy. 2020.

5. TABARY M, KHANMOHAMMADI S, ARAGHI F, DADKHAHFAR S, TAVANGAR SM. Pathologic Features of COVID-19: A Concise Review. Pathology-Research and Practice. 2020:153097.

6. XU X, CHEN P, WANG J, FENG J, ZHOU H, LI X, et al. Evolution of the novel coronavirus from the ongoing Wuhan outbreak and modeling of its spike protein for risk of human transmission. Science China Life Sciences. 2020; 63(3):457-60.

7. HE F, DENG Y, LI W. Coronavirus Disease 2019 (COVID-19): What we know? Journal of Medical Virology. 2020.

8. WANG D, HU B, HU C, ZHU F, LIU X, ZHANG J, et al. Clinical characteristics of 138 hospitalized patients with 2019 novel coronavirus-infected pneumonia in Wuhan, China. Jama. 2020.

9. CHEN N, ZHOU M, DONG X, QU J, GONG F, HAN Y, et al. Epidemiological and clinical characteristics of 99 cases of 2019 novel coronavirus pneumonia in Wuhan, China: a descriptive study. The Lancet. 2020; 395(10223):507-13.

10. HUANG C, WANG Y, LI X, REN L, ZHAO J, HU Y, et al. Clinical features of patients infected with 2019 novel coronavirus in Wuhan, China. The Lancet. 2020; 395(10223):497-506.

11. SHI H, HAN X, JIANG N, CAO Y, ALWALID O, GU J, et al. Radiological findings from 81 patients with COVID-19 pneumonia in Wuhan, China: a descriptive study. The Lancet Infectious Diseases. 2020.

12. XU X, YU C, QU J, ZHANG L, JIANG S, HUANG D, et al. Imaging and clinical features of patients with 2019 novel coronavirus SARS-CoV-2. Eur J Nucl Med Mol Imaging. 2020; 47(5):1275-80. 
13. YOON SH, LEE KH, KIM JY, LEE YK, KO H, KIM KH, et al. Chest radiographic and CT findings of the 2019 novel coronavirus disease (COVID-19): analysis of nine patients treated in Korea. Korean Journal of Radiology. 2020; 21(4):494-500.

14. FANG Y, ZHANG H, XIE J, LIN M, YING L, PANG P, et al. Sensitivity of chest CT for COVID-19: comparison to RT-PCR. Radiology. 2020:200432.

15. CHEN J, QI T, LIU L, LING Y, QIAN Z, LI T, et al. Clinical progression of patients with COVID-19 in Shanghai, China. Journal of Infection. 2020.

16. DACHMAN AH, MACENEANEY PM, ADEDIPE A, CARLIN M, SCHUMM LP. Tumor size on computed tomography scans: is one measurement enough? Cancer. 2001; 91(3):555-60.

17. KSIAZEK TG, ERDMAN D, GOLDSMITH CS, ZAKI SR, PERET T, EMERY S, et al. A novel coronavirus associated with severe acute respiratory syndrome. The New England journal of medicine. 2003; 348(20):1953-66.

18. KUIKEN T, FOUCHIER RA, SCHUTTEN M, RIMMELZWAAN GF, VAN AMERONGEN G, VAN RIEL D, et al. Newly discovered coronavirus as the primary cause of severe acute respiratory syndrome. Lancet (London, England). 2003; 362(9380): $263-70$.

19. DE GROOT RJ, BAKER SC, BARIC RS, BROWN CS, DROSTEN C, ENJUANES L, et al. Middle East respiratory syndrome coronavirus (MERS-CoV): announcement of the Coronavirus Study Group. Journal of virology. 2013; 87(14):7790-2.

20. ZAKI AM, VAN BOHEEMEN S, BESTEBROER TM, OSTERHAUS AD, FOUCHIER RA. Isolation of a novel coronavirus from a man with pneumonia in Saudi Arabia. The New England journal of medicine. 2012; 367(19):1814-20.

21. AJLAN AM, AHYAD RA, JAMJOOM LG, ALHARTHY A, MADANI TA. Middle East respiratory syndrome coronavirus (MERS-CoV) infection: chest CT findings. AJR American journal of roentgenology. 2014; 203(4):782-7.

22. DAS KM, LEE EY, ENANI MA, ALJAWDER SE, SINGH R, BASHIR S, et al. CT correlation with outcomes in 15 patients with acute Middle East respiratory syndrome coronavirus. American Journal of Roentgenology. 2015; 204(4):736-42.

23. WONG KT, ANTONIO GE, HUI DS, LEE N, YUEN EH, WU A, et al. Thin-section CT of severe acute respiratory syndrome: evaluation of 73 patients exposed to or with the disease. Radiology. 2003; 228(2):395-400.

24. CHOI WJ, LEE KN, KANG EJ, LEE H. Middle East Respiratory Syndrome-Coronavirus Infection: A Case Report of Serial Computed Tomographic Findings in a Young Male Patient. Korean J Radiol. 2016; 17(1):166-70.

25. WAN Y-L, TSAY P-K, CHEUNG Y-C, CHIANG P-C, WANG C-H, TSAI Y-H, et al. A correlation between the severity of lung lesions on radiographs and clinical findings in patients with severe acute respiratory syndrome. Korean journal of radiology. 2007; 8(6):466-74.

26. XU X, YU C, QU J, ZHANG L, JIANG S, HUANG D, et al. Imaging and clinical features of patients with 2019 novel coronavirus SARS-CoV-2. European Journal of Nuclear Medicine and Molecular Imaging. 2020:1-6.

27. CHONG S, KIM TS, CHO EY. Herpes simplex virus pneumonia: high-resolution CT findings. The British journal of radiology. 2010; 83(991):585-9.

28. KOO HJ, LIM S, CHOE J, CHOI SH, SUNG H, DO KH. Radiographic and CT Features of Viral Pneumonia. Radiographics: a review publication of the Radiological Society of North America, Inc. 2018; 38(3):719-39.

29. QURESHI NR, HIEN TT, FARRAR J, GLEESON FV. The radiologic manifestations of H5N1 avian influenza. Journal of thoracic imaging. 2006; 21(4):259-64.

30. NG M-Y, LEE EY, YANG J, YANG F, LI X, WANG H, et al. Imaging profile of the COVID-19 infection: radiologic findings and literature review. Radiology: Cardiothoracic Imaging. 2020; 2(1):e200034.

31. FANG Y, ZHANG H, XU Y, XIE J, PANG P, JI W. CT manifestations of two cases of 2019 novel coronavirus (2019-nCoV) pneumonia. Radiology. 2020:200280.

32. KONG W, AGARWAL PP. Chest imaging appearance of COVID-19 infection. Radiology: Cardiothoracic Imaging. 2020; 2(1):e200028.

33. KO JP, SHEPARD J-AO, SPROULE MW, TROTMAN-DICKENSON B, DRUCKER EA, GINNS LC, et al. CT manifestations of respiratory syncytial virus infection in lung transplant recipients. Journal of computer assisted tomography. 2000; 24(2):235-41.

34. FRANQUET T, LEE KS, MÜLLER NL. Thin-section CT findings in 32 immunocompromised patients with cytomegalovirus pneumonia who do not have AIDS. American Journal of Roentgenology. 2003; 181(4):1059-63.

35. VENKATARAMAN T, FRIEMAN MB. The role of epidermal growth factor receptor (EGFR) signaling in SARS coronavirusinduced pulmonary fibrosis. Antiviral research. 2017; 143:142-50.

Received $18^{\text {th }}$ June 2020 